\title{
Paralysis Developing as a Paradoxical Response During Treatment for Tuberculous Spondylitis
}

\author{
Safak Ekinci, $\mathrm{MD}^{1}$, Faruk Akyildiz, $\mathrm{MD}^{2}$, Yavuz Poyrazoglu, $\mathrm{MD}^{3}$, Samet Verim, $\mathrm{MD}^{4}$ \\ ${ }^{1}$ Department of Orthopaedic Surgery, Agri Military Hospital, Agri; ${ }^{2}$ Department of Orthopaedic Surgery, \\ Malatya Military Hospital, Malatya; ${ }^{3}$ Department of General Surgery, Mevki Military Hospital, Ankara; \\ ${ }^{4}$ Department of Radiology, Gulhane Military Hospital, Ankara, Turkey
}

\section{Dear Editor}

We read with great interest the published article by Park et al. [1] entitled "Paralysis Developing as a Paradoxical Response During the Treatment for Tuberculous Spondylitis: A Case Report". The authors report the case of a 69-year-old woman who experienced bilateral lower extremity paralysis secondary to a paradoxical response. We think several more points should be discussed concerning therapy.

Spinal tuberculosis is the most common and the worst form of tuberculosis lesions in the skeleton [2-4]. If the lesion is limited to the vertebrae and there are no complications, triple-drug anti-tuberculous chemotherapy can be the main therapy to treat tuberculosis [5]. However, with proper indications, surgical procedures are superior in the prevention of neurological deterioration, maintenance of stability and early recovery [3-6].

Oguz et al. [4] reported on 76 cases with spinal tuberculosis between 1989 to 2002 without any neurological deterioration that all featured eventual excellent recovery. As a result, these authors developed a effective classifica-

\section{Corresponding author: Safak Ekinci}

Department of Orthopaedic Surgery, Agri Military Hospital, Agri, Turkey Tel: +90-5327339850, Fax: +90-4722152747, E-mail: safakekinci@yahoo. com

(c) This is an open-access article distributed under the terms of the Creative Commons Attribution Non-Commercial License (http://creativecommons. org/licenses/by-nc/3.0) which permits unrestricted noncommercial use, distribution, and reproduction in any medium, provided the original work is properly cited.

Copyright (C) 2015 by Korean Academy of Rehabilitation Medicine tion system abbreviated GATA (Gulhane Askeri Tip Akademisi). This new classification system has been using as a practical guide in the treatment of Pott disease.

In the case that was presented in the article, despite the initiation of medical treatment, deterioration in the clinical status of the patient was observed. However, when we examined the MRI in Fig. 1, we noted vertebral collapse and abcess formation, which is type II in the GATA classification system. Type II treatment is anterior debridement and fusion.

As a result, we believe that if surgical intervention is made at the time of diagnosis (early stage), the patient will heal more quickly without any neurological deterioration.

\section{CONFLICT OF INTEREST}

No potential conflict of interest relevant to this article was reported.

\section{REFERENCES}

1. Park JH, Kim YH, Kwon CH, Shin HI. Paralysis developing as a paradoxical response during the treatment for tuberculous spondylitis: a case report. Ann Rehabil Med 2014;38:405-9.

2. Boachie-Adjei O, Squillante RG. Tuberculosis of the spine. Orthop Clin North Am 1996;27:95-103.

3. Rezai AR, Lee M, Cooper PR, Errico TJ, Koslow M. Modern management of spinal tuberculosis. Neuro- 
surgery 1995;36:87-98.

4. Oguz E, Sehirlioglu A, Altinmakas M, Ozturk C, Komurcu M, Solakoglu C, et al. A new classification and guide for surgical treatment of spinal tuberculosis. Int Orthop 2008;32:127-33.

5. Moon MS, Moon YW, Moon JL, Kim SS, Sun DH. Conservative treatment of tuberculosis of the lum- bar and lumbosacral spine. Clin Orthop Relat Res 2002;(398):40-9.

6. Ghadouane M, Elmansari O, Bousalmame N, Lezrek K, Aouam H, Moulay I. Role of surgery in the treatment of Pott's disease in adults: apropos of 29 cases. Rev Chir Orthop Reparatrice Appar Mot 1996;82:620-8. 